\title{
Reasons for Declining Venom Immunotherapy
}

\section{Motivos de Recusa de Imunoterapia com Veneno de Himenópteros}

\author{
Leonor CARNEIRO-LEÃO ${ }^{1}$, Luís AMARAL ${ }^{1}$, Alice COIMBRA ${ }^{1}$ \\ Acta Med Port 2018 Nov;31(11):618-623 - https://doi.org/10.20344/amp.9695
}

\section{ABSTRACT}

Introduction: Hymenoptera venom allergy is associated with significant morbidity and deterioration in health-related quality of life, and risk of fatal systemic reactions. Although venom immunotherapy is safe and the only effective treatment in allergic individuals, some patients prefer not to pursue this treatment. Since 2011 , when the $50 \%$ reimbursement was stopped, patients must fully support the cost of immunotherapy. This study aimed to ascertain the reasons why patients decline immunotherapy.

Material and Methods: A medical records review of all patients proposed to receive venom immunotherapy at an Allergy and Clinical Immunology Department in Porto, Portugal, between 2006 and 2015, followed by a phone interview to patients refusing treatment.

Results: A total of 83 subjects were enrolled, with a mean ( \pm SD) age of 44.4 (14.7) years and $55(66 \%)$ males; 27 refused venom immunotherapy between 2006 and 2015. Nineteen were interviewed and 14 of those stated price as the main reason for declining treatment. The only identified risk factor associated with immunotherapy refusal was being proposed after 2011 (OR: 3.29 ; $95 \% \mathrm{Cl}$ : $1.12-9.68 ; p=0.03)$.

Discussion: The number of patients refusing venom immunotherapy doubled since reimbursement was withdrawn. Price was identified as the major obstacle to treatment completion. Immunotherapy proposal after reimbursement was stopped was associated with a 3-fold increase in the risk of refusing treatment.

Conclusion: These findings show how economic decisions may have a detrimental effect on patient care, as immunotherapy refusal left them exposed to an avoidable life-threatening risk.

Keywords: Hymenoptera; Hypersensitivity; Immunotherapy; Insect Bites and Stings; Venom

\section{RESUMO}

Introdução: A alergia a veneno de himenópteros está associada a uma significativa morbilidade e diminuição da qualidade de vida, bem como a risco de reações alérgicas fatais. Apesar da imunoterapia com veneno de himenópteros ser um tratamento seguro e o único eficaz nesta patologia, alguns doentes decidem não o realizar. Desde 2011, quando a comparticipação de 50\% terminou, o custo da imunoterapia é totalmente suportado pelos doentes. Este trabalho pretendeu identificar os motivos da recusa desta terapêutica.

Material e Métodos: Revisão dos registos clínicos de todos os doentes propostos para imunoterapia com veneno de himenópteros num serviço de Imunoalergologia, no período 2006 - 2015, seguida de entrevista telefónica aos que a recusaram.

Resultados: Foram incluídos 83 doentes, com uma idade média ( \pm DP) de 44,4 (14,7) anos. Cinquenta e cinco $(66 \%)$ eram homens; 27 recusaram imunoterapia entre 2006 e 2015. Dezanove foram entrevistados e 14 identificaram o preço como principal motivo de recusa. O único fator de risco identificado para a recusa de imunoterapia foi ser proposta depois de 2011 (OR: 3,29; $95 \%$ Cl: 1,12 $9,68 ; p=0,03)$.

Discussão: O número de doentes a recusar imunoterapia duplicou desde que a comparticipação foi retirada. O preço foi o principal obstáculo à realização do tratamento. Ser proposto após o término da comparticipação do tratamento aumentou em três vezes o risco de recusa.

Conclusão: Estes achados revelam o impacto negativo de uma decisão económica na saúde e segurança destes doentes, já que a recusa da imunoterapia os manteve expostos a um risco de vida evitável.

Palavras-chave: Himenópteros; Hipersensibilidade; Imunoterapia; Mordeduras e Picadas de Insectos; Veneno

\section{INTRODUCTION}

Hymenoptera venom allergy (HVA) is generally a serious life-threatening condition and it is responsible for more than $10 \%$ of all cases of anaphylaxis attending emergency departments. ${ }^{1}$ It affects up to $5 \%$ of the general population ${ }^{2}$ and up to $32 \%$ of beekeepers. ${ }^{3}$ Epidemiological studies suggest a prevalence of self-reported anaphylactic sting reactions between $0.3 \%$ and $7.5 \%{ }^{4}$ Hymenoptera reactions are responsible for about a quarter of fatalities due to anaphylaxis. ${ }^{5}$ Moreover, due to the fear of future reactions, HVA imposes a significant impact in health-related quality of life $(\mathrm{QoL})^{6}$ and causes work disability. ${ }^{7}$

Numerous insects can induce allergic reactions. However only the insect stings of the order Hymenoptera can cause fatal reactions. From a medical perspective, the more relevant ones belong to the families vespidae, apidae and fomicidae; in Europe only Apidae (apis mellifera and bombus terrestris) and Vespidae (vespula, vespa, polistes) are pertinent. ${ }^{8}$

Every patient reporting a systemic allergic reaction after a sting should undergo a complete allergy work-up, which should include a detailed history, specific IgE to suspected hymenoptera venom and basal serum tryptase measurements, prick and intradermal skin tests to the suspected insect venom. ${ }^{9,10}$

Management of HVA is based on avoidance measures, availability of emergency treatment and venom immunotherapy (VIT). ${ }^{6,9,10}$ VIT is the only treatment option with an immunomodulatory effect that results in a decreased risk

1. Serviço de Imunoalergologia. Centro Hospitalar de São João. Porto. Portugal.

$\triangle$ Autor correspondente: Leonor Carneiro-Leão. leonorcarneiroleao@gmail.com

Recebido: 19 de setembro de 2017 - Aceite: 01 de agosto de 2018 | Copyright @ Ordem dos Médicos 2018 
and severity of future sting induced systemic reactions. ${ }^{6,9,10}$

VIT is safe and induces tolerance to hymenoptera venom, providing long-term protection from further systemic reactions in $95 \%$ of patients allergic to wasp venom, and approximately $80 \%$ of those allergic to bee venom. ${ }^{11}$ However, the mechanism behind this tolerance induction is not fully understood. It also improves health related QoL. ${ }^{12,13}$ VIT should be offered to children and adults with a history of severe systemic reaction and documented sensitization to the respective insect with either positive skin tests and/ or elevated specific IgE.6,9,10,14 Unless additional risk factors are present (raised baseline tryptase, a high likelihood of future sting or impact on QoL), VIT is usually not indicated for less severe sting induced reactions., ${ }^{6,9-11}$

Essentially, VIT consists in the subcutaneous administration of the selected venom extract, with an initial induction phase, followed by a maintenance phase. In the induction phase serial doses of venom extract are administered, building-up until a protective dose of $100 \mu \mathrm{g}$ of venom extract is reached. Induction protocols are varied, lasting from 2 to 6 weeks. Maintenance phase consists in the administration of $100 \mu \mathrm{g}$ of venom extract at scheduled intervals. There is a generalized consensus that intervals should be of 4 weeks for the first year and may then be extended to 6 weeks The overall duration of VIT is 3 to 5 years but can be longer in selected patients. ${ }^{6,9,10}$ VIT administration carries a small but serious risk of anaphylaxis and, for that reason, it should be managed by an experienced allergist, in a hospital setting. ${ }^{6,9,10}$

In addition to being time consuming, VIT is also costly. Venom extracts are commercially available for honeybee, wasp and paper wasp. In 2012, National Institute for Health and Care Excellence (NICE) estimated a cost per injection of $£ 54.81$ for bee venom, and of $£ 67.20$ for wasp venom extract during the induction phase; for maintenance, the price per injection varied from $£ 15.94$ for bee venom, to $£ 20.51$ to wasp venom extract. ${ }^{15}$ In Portugal, prices per injection vary from $€ 37.6$ to $€ 124.20$ during induction and from $€ 36.04$ to $€ 47.85$ during the maintenance phase. A small Portuguese study concluded that the median yearly cost of VIT was $€ 1549$, including $€ 438$ for VIT extract purchase, $€ 218$ for hospital visits, and $€ 787$ for work hours loss. ${ }^{16}$

Allergen immunotherapy had a $50 \%$ reimbursement by the National Health Service in Portugal until it was stopped in 2011, a period of economic and financial crisis. This decision was contested by physicians, patients, the national allergy and clinical immunology scientific society and the Portuguese Medical Association. Nonetheless, reimbursement was stopped and so the burden of VIT became entirely supported by the patients.

The purpose of this study was to examine the reasons why patients declined VIT, as well as to assess the impact of VIT price and reimbursement withdrawal on their decision.

\section{MATERIAL AND METHODS}

Medical records of all patients with clinical indication for
VIT, according to European Academy of Allergy and Clinical Immunology (EAACI) guidelines ${ }^{6,14}$ at an Allergy and Clinical Immunology Department of a tertiary care hospital in Porto, Portugal, between 2006 and 2015 were reviewed. Data regarding demographics, sting reaction severity according to Mueller's criteria, ${ }^{17}$ suspected hymenoptera involved, specific IgE, venom skin tests, type of VIT proposed, dates of proposal, first and last administration and treatment completion was collected. Premature interruption was defined when the patient stopped VIT before the scheduled date. The term price refers to the amount spent by patients for purchasing the relevant hymenoptera venom extract (commonly known as 'allergen vaccine'); cost refers to the total amount of money spent during treatment, including hospital visits, work hours lost, etc.

A structured questionnaire was applied by phone to patients who had declined VIT (Fig. 1). Information was gathered on the reasons why patients decided against VIT, new field stings (accidental hymenoptera stings), severity of subsequent reactions and use of adrenaline auto-injectors (AAI).

Statistical analysis was performed using IBM SPSS Statistics ${ }^{\circledR}$, version 20.0. Continuous variables are expressed as means and standard deviations; categorical variables were expressed as frequencies and percentages. Independent t-test was used to compare mean age between groups. Chi-squared test, which tests whether two categorical variables are independent or not, was used to identify differences among groups. Risk factors for VIT refusal were assessed using univariate binary logistic regression analysis, using age, sex, comorbid allergic diseases, type of profession (primary, secondary or tertiary sectors), type of VIT proposed, severity of previous reactions, feeling of impending doom during the reactions and VIT being proposed after 2011 as independent variables. Assessment of the discriminatory performance of the model was conducted using Nagelkerke $\mathrm{R}^{2}$ and area under the receiver-operating curve (AUC). The results are expressed as odds ratios (ORs) and 95\% confidence intervals (Cls); $p<0.05$ was considered statistically significant.

\section{RESULTS}

A total of 83 patients had indication for VIT, 44 (53\%) between 2006 and 2010 and 39 (47\%) between 2011 and 2015. No significant differences were detected between the two groups besides the number of patients refusing VIT: 27 refused treatment, 9 (21\%) of them in $2006-2010$ period and $18(46 \%)$ in the $2011-2015$ period $(\chi 2(1)=6.221$; $p=0.013)$. The patient flow chart is illustrated in Fig. 2. Table 1 presents the clinical characteristics of patients refusing and undergoing VIT. Also, nine patients decided to stop VIT prematurely, eight of them after 2011. Univariate logistic regression identified being proposed after 2011 as the only variable contributing to VIT refusal and it was strongly associated to a higher risk of refusal (OR: $3.29 ; 95 \% \mathrm{Cl}: 1.12$ - 9.68; $p=0.03$ ) (results shown in Table 2). Assessment of the discriminatory performance of the model revealed 
a poor predictive capacity: low Nagelkerke $R^{2}(0.101)$ and AUC (0.646).

\section{Phone interviews}

Nineteen of the 27 patients declining VIT agreed to be interviewed by phone. Of these, $17(89 \%)$ stated that price influenced their decision not to undergo VIT; 14 (73.7\%) identified it as the major reason for declining treatment and $4(21.1 \%)$ indicated difficulties in obtaining time off work once a month for hospital visits. Seventeen (89.5\%) and $10(52.6 \%)$ would have accepted VIT if it was fully or partially reimbursed (50\%), respectively. Since refusing VIT, 11 $(57.9 \%)$ were re-stung and 9 of them had another anaphy- lactic episode with 7 attending an emergency department. No fatalities or hospitalizations were reported. One patient changed profession, 5 changed hobbies and another 5 avoided outdoor activities because of this allergy. Seven admitted not purchasing nor carrying their prescribed AAI. Six of these stated they would have redeemed their prescription if it was $50 \%$ cheaper.

\section{DISCUSSION}

VIT is the first line of treatment in hymenoptera venom allergic patients suffering severe systemic reactions with documented sensitization to the suspected insect. However, this treatment is expensive and, in Portugal, the onus

1. Please indicate which of the following reasons led you to refuse the hymenoptera venom immunotherapy

- Fear of reaction?

- Fear of needles?

- Another fear related to the treatment? Please state which.

- Treatment price?

- Costs related to the transportation to the hospital?

- Other costs? Please state which.

- Difficulties in obtaining time off work for hospital visits?

- Another? Please state which.

2. If VIT was free, would you undergo it?

3. If VIT cost $50 \%$ less, would you accept undergo it?

4. Which reason was the most decisive? What was the most decisive reason?

5 . Do you take any medication for this allergy?

6. Please indicate which medication do you take for this allergy:

- Antihistamines? Which? Annual cost?

- Insect repellent? Which? Annual cost?

- Oral steroids? Which? Annual cost?

- Adrenaline auto-injector? Which? Annual cost?

7. Do you have an adrenaline auto-injector?

(If answering YES)

7.1 Please state which.

7.2 Are you carrying it at this moment?

7.3 Do you carry it with you:

- Less than $50 \%$ of the time

- About $50 \%$ of the time

- More than $50 \%$ of the time

- At all times

7.3.1 Why don't you always carry your adrenaline auto-injector with you? (to be answered only if not carrying it at all times)

7.4 How many adrenaline auto-injectors have you bought since being refused VIT?

(If answering NO)

7.5 When did you stop buying it?

7.6 Why have you decided not to buy it?

7.7 If adrenaline auto-injectors were free would you carry it?

7.7.1 If adrenaline auto-injectors cost $50 \%$ less, would you carry it?

8. Have you changed your profession because of this allergy?

9. Have you changed your hobbies because of this allergy?

10. Have you stopped visiting outdoor spaces in your free time because of this allergy?

11. Have you been stung again since refusing VIT $h$ ?

(If answering NO)

11.1 If you suffered another severe reaction again, would you reconsider your decision to decline VIT?

(If answering YES)

11.2 Where on your body have you been stung?

11.3 Where were you when you were stung?

11.4 What were you doing when you were stung?

11.5 Please describe the reaction.

11.6 Did you take any medication? Please state which.

11.7 Did you go to the emergency department?

11.8 Were you admitted to the hospital?

11.8.1 For how long?

11.8.2 Where were you admitted ( $\mathrm{UCl}$, normal hospital ward/ other?)

11.9 How many hours of work have you lost?

11.10 Was any medication prescribed? Please state which.

12. Do you want to make any comment or statement on this matter?

Figure 1 - Questionnaire applied during the phone interview (translated from Portuguese) 


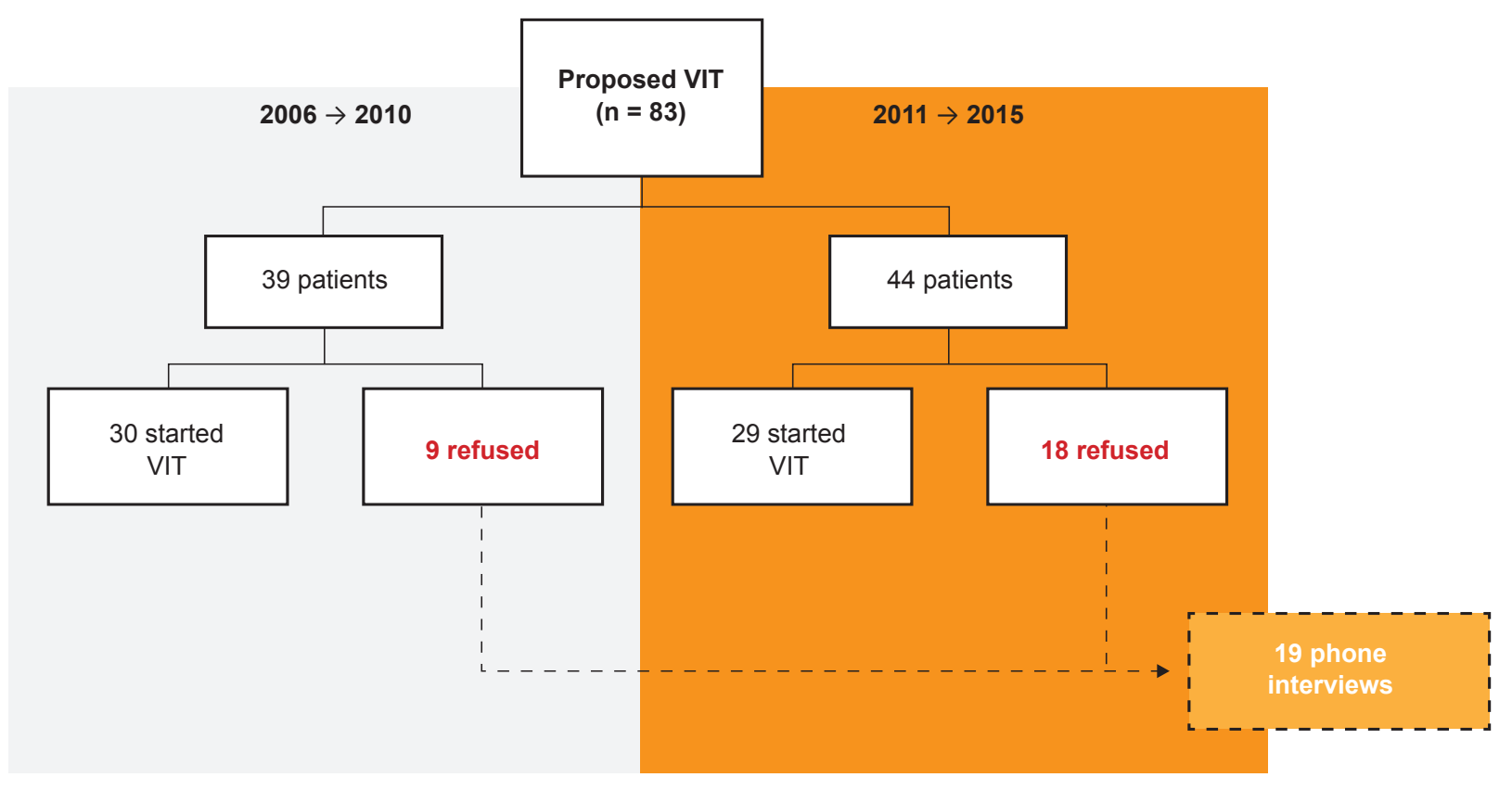

Figure 2 - Patient flow chart

is entirely supported by patients since 2011 . In this series, a significant increase in the number of patients refusing treatment was observed since the reimbursement was withdrawn. A greater than two-fold increase was found when comparing the 5-year periods before and after the changes in reimbursement policy. Furthermore, VIT being proposed after 2011 was the only identified risk-factor for not undergoing this treatment, with a greater than threefold increase in this risk. However, this last result should be interpreted carefully, as the model on which it was based showed a poor performance on discriminatory assessment measures - although these results were to be expected, given the small sample size and the characteristics of the variables included in the model. Phone interviews with the patients refusing VIT further confirmed the impact of price in treatment adherence, as the vast majority identified this as the major reason to decline treatment. VIT is an expensive treatment, especially if all associated costs are considered, including not only its price, but also work hours lost and the cost of hospital visits. In 2016, the average wage in Portugal was $€ 924,{ }^{18}$ remaining below the European average; in $2016,23.3 \%$ of workers earned the minimum wage of $€ 557 .{ }^{19,20}$ In this setting, it seems reasonable to expect that the average Portuguese individual will struggle to support all treatment expenses.

Price was again reported as an obstacle for carrying an AAl. Patient safety was indeed impaired since a significant percentage suffered new field stings and subsequent anaphylaxis.

VIT safety and clinical efficacy are well established. Although its cost-effectiveness has been a matter of debate, a NICE health technology assessment showed that when patients at a high risk of stings or when a small increase in QoL are considered, VIT is a cost-effective treatment. ${ }^{15}$ Taking these characteristics into consideration, the 2011 decision to stop reimbursement is debatable from a clinical and health economics standpoint.

This study was limited by its retrospective design, the

Table 1 - Patient demographics

\begin{tabular}{lcc}
\hline & $\begin{array}{c}\text { Population demographics } \\
\mathrm{n}=83\end{array}$ & $55(66 \%)$ \\
Male sex & & $44.4( \pm 14.7)$ \\
Age, mean ( \pm SD) & & $19(20 \%) / 39(47 \%)$ \\
Beekeeper / Beekeeper family & & $20(24 \%)$ \\
Sensitized to aeroallergens & & $4(5 \%)$ \\
Asthma & & $12(15 \%)$ \\
Rhinitis & Bee & $15(18 \%)$ \\
Cardiovascular disease & Wasp & $52(63 \%)$ \\
Proposed VIT & Paper wasp & $29(35 \%)$ \\
\end{tabular}


Table 2 - Univariate logistic regression results

\begin{tabular}{|c|c|c|c|c|}
\hline & $n$ & $p$ value & Crude OR & $95 \% \mathrm{Cl}$ \\
\hline \multicolumn{5}{|l|}{ Sex } \\
\hline Male & 55 & Reference & & \\
\hline Female & 28 & 0.957 & 0.974 & $0.368-2.576$ \\
\hline Age & & 0.699 & 1.006 & $0.975-1.038$ \\
\hline \multicolumn{5}{|l|}{ Proposed VIT } \\
\hline Paper wasp & 2 & Reference & & \\
\hline Bee & 52 & 0.533 & 0.405 & $0.024-6.911$ \\
\hline Wasp & 29 & 0.737 & 0.611 & $0.035-10.79$ \\
\hline \multicolumn{5}{|l|}{ Sector } \\
\hline Primary & 11 & Reference & & 1 \\
\hline Secondary & 27 & 0.648 & 1.400 & $0.330-5.933$ \\
\hline Terciary & 29 & 0.911 & 0.921 & $0.217-3.917$ \\
\hline Student & 9 & 0.217 & 0.219 & $0.020-2.447$ \\
\hline \multicolumn{5}{|l|}{ Beekeeper } \\
\hline No & 65 & Reference & & \\
\hline Yes & 17 & 0.816 & 1.143 & $0.372-3.511$ \\
\hline \multicolumn{5}{|l|}{ Allergic comorbidities } \\
\hline No & 60 & Reference & & \\
\hline Yes & 20 & 0.783 & 0.857 & $0.286-2.567$ \\
\hline \multicolumn{5}{|c|}{ Cardiovascular comorbidities } \\
\hline No & 67 & Reference & & \\
\hline Yes & 15 & 0.970 & 1.203 & $0.312-3.357$ \\
\hline Mueller severity score & & 0.390 & 1.317 & $0.703-2.466$ \\
\hline \multicolumn{5}{|c|}{ Feeling of impending doom } \\
\hline No & 74 & Reference & & \\
\hline Yes & 6 & 0.964 & 1.042 & $0.178-6.090$ \\
\hline \multicolumn{5}{|l|}{ VIT proposal after 2011} \\
\hline No & 39 & Reference & & \\
\hline Yes & 44 & 0.031 & 3.286 & $1.115-9.681$ \\
\hline
\end{tabular}

inability to contact all patients refusing VIT and by the small sample size. However, we have included all the patients with proved venom allergy attending a large Portuguese Allergy and Clinical Immunology Department.

For years Portuguese allergists have sensed that patients were refusing VIT for economic reasons. Our study is the first confirming this perception and providing evidence of the negative impact of the decision to stop VIT reimbursement.

\section{CONCLUSION}

These results illustrate how economic decisions may have a negative impact on patient adherence to treatment, safety and wellbeing. In this particular case, a detrimental effect on patient care was observed since VIT refusal exposed them to an avoidable life-threatening risk. As the ultimate patient advocates, doctors must be aware of these consequences and defend patients.

\section{PROTECTION OF HUMANS AND ANIMALS}

The authors declare that the procedures were followed according to the regulations established by the Clinical Research and Ethics Committee and to the Helsinki Declaration of the World Medical Association.

\section{DATA CONFIDENTIALITY}

The authors declare having followed the protocols in use at their working center regarding patients' data publication.

\section{CONFLICTS OF INTEREST}

The authors declare no real or perceived conflicts of interest

\section{FUNDING SOURCES}

This research received no specific grant from any funding agency in the public, commercial, or not-for-profit sectors. 


\section{REFERENCES}

1. Manivannan V, Campbell RL, Bellolio MF, Stead LG, Li JT, Decker WW. Factors associated with repeated use of epinephrine for the treatment of anaphylaxis. Ann Allergy Asthma Immunol. 2009;103:395-400.

2. Bonadonna P, Schiappoli M, Dama A, Olivieri M, Perbellini L, Senna G, et al. Is hymenoptera venom allergy an occupational disease? Occup Environ Med. 2008;65:217-8.

3. Bilo BM, Bonifazi F. Epidemiology of insect-venom anaphylaxis. Curr Opin Allergy Clin Immunol. 2008;8:330-7.

4. Bilo MB, Bonifazi F. The natural history and epidemiology of insect venom allergy: clinical implications. Clin Exp Allergy. 2009;39:1467-76.

5. Sturm GJ, Varga EM, Roberts G, Mosbech H, Bilò MB, Akdis CA, et al. EAACl guidelines on allergen immunotherapy: Hymenoptera venom allergy. Allergy. 2018;73:744-64.

6. Silva D, Pereira M, Santos N, Amaral L, Delgado L, Oude Elberink $\mathrm{JN}$, et al. The vespid allergy quality of life questionnaire - cultural adaptation and translation to Portuguese. Eur Ann Allergy Clin Immunol. 2017;49:114-21.

7. Paolocci G, Folletti I, Toren K, Muzi G, Murgia N. Hymenoptera venom allergy: work disability and occupational impact of venom immunotherapy. BMJ Open. 2014;4:e005593.

8. Matricardi PM, Kleine-Tebbe J, Hoffmann HJ, Valenta R, Hilger C, Hofmaier S, et al. EAACI Molecular Allergology User's Guide. Pediatr Allergy Immunol. 2016;27:1-250.

9. Golden DB, Moffitt J, Nicklas RA, Freeman T, Graft DF, Reisman RE, et al. Stinging insect hypersensitivity: a practice parameter update 2011. J Allergy Clin Immunol. 2011;127:852-4.

10. Golden DB, Demain J, Freeman T, Graft D, Tankersley M, Tracy J, et al. Stinging insect hypersensitivity. Ann Allergy Asthma Immunol. 2017;118:28-54.

11. Krishna MT, Ewan PW, Diwakar L, Durham SR, Frew AJ, Leech SC, et al. Diagnosis and management of hymenoptera venom allergy: British Society for Allergy and Clinical Immunology (BSACl) guidelines. Clin Exp Allergy. 2011;41:1201-20.

12. Oude Elberink JN, De Monchy JG, Van Der Heide S, Guyatt GH, Dubois AE. Venom immunotherapy improves health-related quality of life in patients allergic to yellow jacket venom. J Allergy Clin Immunol. 2002;110:174-82.

13. Boyle RJ, Elremeli M, Hockenhull J, Cherry MG, Bulsara MK, Daniels M, et al. Venom immunotherapy for preventing allergic reactions to insect stings. Cochrane Database Syst Rev. 2012;10:CD008838.

14. Bonifazi F, Jutel M, Bilo BM, Birnbaum J, Muller U. Prevention and treatment of hymenoptera venom allergy: guidelines for clinical practice. Allergy. 2005;60:1459-70.

15. Excellence NIfHaC. Pharmalgen for the treatment of bee and wasp venom allergy. London: National Institute for Health and Care Excellence; 2012.

16. Silva D, Pereira A, Coimbra A. Qualidade de vida e custo económico da imunoterapia na alergia a veneno de himenópteros. Rev Port Imunoalergol. 2012;20:S5-50.

17. Mueller HL. Diagnosis and treatment of insect sensitivity. J Asthma Res. 1966;3:331-3.

18. PORDATA. Salário médio mensal dos trabalhadores por conta de outrem: remuneração base e ganho. 2018. [accessed 2018 March 16] Available at: https://www.pordata.pt/.

19. PORDATA. Trabalhadores por conta de outrem com salário mínimo nacional por sector de actividade económica - Continente (\%). 2018 [accessed 2018 Mar 16]. Available at: https://www.pordata.pt/.

20. PORDATA. Salário mínimo nacional. 2018. [accessed 2018 Mar 16]. Available at: https://www.pordata.pt/. 